\title{
Oncogenic herpesvirus infections of animals
}

\author{
P. M. BIGGS \\ From Houghton Poultry Research Station, Houghton, Huntingdon
}

When considering the writing of this paper I was troubled by the fact that one series of papers in this symposium was included under the heading of 'persistent infections' and another, of which this is one, under the heading of 'latent infections'. On reflection I could not see why some subjects included in persistent infections could not have been classed as latent infections and vice versa. Consequently I resorted to the dictionary for definitions. The answer, of course, is that the two states are not mutually exclusive and in fact are frequently present together, and this is reflected in the title of this symposium.

As far as virus-host relationships and resulting disease are concerned I believe the definitions given in the Shorter Oxford dictionary are pertinent. Persistent is briefly defined as something which is 'permanent or continuing'. This definition is easily applied to infection with a virus. Latent is more difficult but is defined as 'hidden or concealed'; or applied to disease, as 'present or existing but not manifest, exhibited or developed'. This definition can be used in respect of (1) the infection or (2) the development of disease, and indeed in the past has been used in both these respects.

In its extreme form a latent infection could be considered that in which there is no evidence of infection, eg, where the virus genome or a copy is integrated with the host DNA and is in a repressed state. This may be one of the states of infection with RNA tumour viruses. However, more commonly and classically a latent infection has been applied to that state in which infectious virus cannot be identified, eg, Herpes simplex infection in man, although fingerprints of infection such as antibodies or antigens may be demonstrable. Latency of infection may be considered at the level of the whole animal or at a cellular level. Lastly, latency can be applied to the disease produced by a virus infection. The term 'latent period' is sometimes used to describe the incubation period when it is long or variable in length. A latent infection, and latency in respect of disease, may in some cases be one and the same thing.

It is my intention to discuss those herpesvirus infections in animals other than man which have been associated with neoplasia in some way or another, paying particular attention to latency and persistence of infection. First there are those herpesviruses which are known to cause neoplasia under natural conditions, which include the herpesviruses of Marek's disease and the Lucké renal carcinoma of frogs; secondly, Herpesvirus saimiri, and Herpesvirus ateles of monkeys and Herpesvirus sylvilagus of cottontail rabbits which cause lymphoid neoplasia experimentally but their significance as aetiological agents of neoplasia under natural conditions is not known; thirdly those herpesviruses which have been associated with neoplasia in guinea pigs and sheep but whose oncogenicity in either experimental or natural conditions has yet to be proven. A brief outline of the relevent features of infection with herpesviruses in groups 2 and 3 will first be given then Marek's disease and the Lucké renal carcinoma of the frog will be discussed in more detail.

\section{Guinea Pig Herpesvirus}

The isolation of a herpesvirus from strain 2 guinea pigs which are highly susceptible to a transmissible lymphoblastoid leukaemia was first reported by Hsiung and Kaplow (1969). This virus, which is unrelated to the cytomegalovirus of guinea pigs (Hsiung, Kaplow, and Booss, 1971), was isolated from 51 out of 58 strain 2 and six out of 17 muta strain guinea pigs which indicated that infection was widespread amongst these strains. Although strain 13 Hartley, and FS strain guinea pigs could be infected experimentally, Hsiung et al (1971) were unable to isolate this herpesvirus from six animals of strain 13, over 100 of Hartley, and 16 of FS strain. The virus was present in the liver, spleen, lung, kidney, salivary gland, and buffy coat cells of the blood from both naturally and experimentaly infected animals. Virus could not be isolated from the blood plasma and was present in a cell-associated state in all tissues, requiring cocultivation with susceptible cells for its detection. Electron microscope studies have not identified immature or mature herpesvirus particles in the tissues of the 
guinea pig which were examined (spleen and salivary gland), although they have been seen in cells cultured from infected animals (Hsiung et al, 1971). Guinea pigs inoculated with this herpesvirus have been kept for more than two years with no evidence of disease. However, neutralizing antibodies were first detected two weeks after inoculation and they persisted throughout life (Hsiung, personal communication). These findings indicate that the guinea pig herpesvirus not only produces a persistent infection but also an infection which is latent in respect of the putative disease and of the absence of production of infectious virus particles.

\section{Herpesvirus Associated with Ovine Pulmonary Adenomatosis (Jaagsiekte)}

The isolation of a herpesvirus in cultured macrophages derived from the lungs of sheep with pulmonary adenomatosis was described by Mackay (1969a and b) and by Smith and Mackay (1969). The virus was isolated from 14 out of 24 sheep with pulmonary adenomatosis, but there is little other evidence to associate the virus with this disease and attempts to reproduce the disease with preparations of the herpesvirus have been inconclusive (Mackay and Nisbet, 1972). There is no information on the behaviour of this virus in sheep under natural conditions and herpesviruses have not been seen in the lesions of pulmonary adenomatosis of 32 sheep studied (Nisbet, Mackay, Smith, and Gray, 1971; Perk, Hod, and Nobel, 1971). These observations suggest that it is a latent infection. Experimentally the virus can be a persistent infection of sheep because Mackay and Nisbet (1972) were able to isolate it from lambs six to 11 months after inoculation.

\section{Herpesvirus Associated with Lymphoma of the Cottontail Rabbit}

Hinze (1969) reported the isolation of a herpesvirus (Herpesvirus sylvilagus) from wild cottontail rabbits which has subsequently been shown to be unrelated to Herpesvirus cuniculi isolated from rabbits of the genus Oryctologus (Hinze, 1971). Cottontail rabbits inoculated with Herpesvirus sylvilagus develop a long-term infection in which virus can be consistently isolated from whole blood but not from serum. Massive infiltration of a number of organs with immature lymphoid cells is seen six to eight weeks after inoculation, a picture Hinze (1969) describes as consistent with a diagnosis of malignant lymphoma. Unfortunately the experiments in rabbits done with this virus have only been reported in abstract and there is little detail available. However, the information reported above suggests that the incuba- tion period is relatively long and that the virus persists in a cell-associated state in the animal, a state which also is found in cell culture (Ley and Burger, 1970).

\section{Herpesviruses Associated with Lymphoma of Monkeys}

Two herpesviruses have been isolated from monkeys which are capable of producing lymphomas but in both cases these tumours have only been produced experimentally in species other than those from which they were isolated. Herpesvirus saimiri was isolated from a squirrel monkey (Saimiri sciureus) (Meléndez, Daniel, Hunt, and Garcia, 1968) and produces lymphomas in owl (Aotus travirgatus), marmoset (Saguinus oedipus), cinnamon ringtail (Cebus albifrons), and African green (Ceropithecus aetiops) and black spider (Ateles geofroyii) monkeys two to 36 weeks after inoculation. Lymphomas have not been noted in squirrel monkeys inoculated with Herpesvirus saimiri (Meléndez, Hunt, Daniel, Garcia, and Fraser, 1969; Hunt, Meléndez, King, Gilmore, Daniel, Williamson, and Jones, 1970; Meléndez, Hunt, Daniel, Blake, and Garcia, 1971). Herpesvirus ateles, which is serologically unrelated to Herpesvirus saimiri, was isolated from a black spider monkey (Ateles geofroyii) and has produced lymphomas in marmosets but not in the species of origin (Meléndez, Hunt, Daniel, Fraser, Barahona, Garcia, and King, 1972).

Antibodies to Herpesvirus saimiri were found in six out of 31 commercially derived squirrel monkeys and in 50 to $70 \%$ of squirrel monkeys brought directly from the wild state (Meléndez et al, 1972). This indicates that the infection is widespread in these monkeys, and if responsible for a fatal disease such as malignant lymphoma it is only a rare response to infection. Unfortunately little study has been made to date on the fate of these viruses after experimental infection of their natural host or other monkeys, or understandably, of their epidemiology in their natural hosts in the wild. Virus recently has been shown to be avidly cell associated in tissues of marmosets experimentally infected with Herpesvirus saimiri, and throughout the infection virus particles and virus-associated antigens could not be demonstrated in tumours and tissues so far examined (Wolfe, Falk, and Deinhardt, 1971). The long period between infection with Herpesvirus saimiri and the development of lymphomas in some owl monkeys (Meléndez et al, 1971) and some marmosets (Wolfe et al 1971), and the high incidence of antibodies in naturally infected squirrel monkeys and experimentaliy infected marmosets suggests that infection with this virus can be latent for long periods in both 
species and is probably also persistent in its natural host the squirrel monkey.

\section{Herpesvirus of Lucké Renal Carcinoma of North American Leopard Frogs (Rana pipiens)}

A renal carcinoma of the North American leopard frog was first described by Lucké in 1934. The observation that cells of these tumours contained Cowdry type A inclusions suggested to Lucké (1938) that they had a viral aetiology. The first indication that this putative virus might be a herpesvirus came from an ultrastructural study by Fawcett (1956) who found particles in the tumour cells with the characteristic morphology of herpesviruses. The finding of a herpesvirus was later corroborated by a number of workers, but difficulties have been encountered in proving unequivocally the aetiological role of this herpesvirus in the Lucké tumour. However circumstantial evidence strongly suggests that it is the aetiological agent and this has been reviewed by Granoff (1972).

The relationship between the Lucké herpesvirus and its host is a particularly interesting one. Although there is much yet to be learnt to understand fully the virus-host relationship and its role in oncogenesis, there are a number of facts worth noting. It would appear that in certain circumstances infection with the Lucké herpesvirus is in the form of the most stringent of the latent states discussed earlier.

Fawcett (1956) noted that a herpesvirus was morphologically present in tumour cells but only in such cells which contained intranuclear inclusions. This observation was subsequently confirmed on many occasions (Lunger, Darlington, and Granoff, 1965; Zambernard and Mizell, 1965; Zambernard, Vatter, and McKinnell, 1966). It was later noted that inclusions and virus were only seen in tumours of frogs kept in the cold and not when they were kept at temperatures above about $15^{\circ} \mathrm{C}$ (Roberts, 1963; Rafferty, 1964). The same observation has been made on tumours collected from frogs in the natural state, for McKinnell and Zambernard (1968) found virus particles in 11 tumours collected in the spring from frogs in lake water with a temperature which varied between 2 and $7^{\circ} \mathrm{C}$, and Zambernard and McKinnell (1969) were unable to find virus particles in 11 tumours collected from frogs in the late summer when the mean minimum temperature was $7^{\circ} \mathrm{C}$ and mean maximum temperature $18^{\circ} \mathrm{C}$. McKinnell and Ellis (1972) have suggested that the 'virus-free' tumours should be called calid (warm) tumours and those containing virus particles algid (cold) tumours.

The question arises as to whether calid tumours are infected by the Lucké herpesvirus. Apart from morphological observations on the absence of virus particles in these tumours, Tweedell (1967) has shown that they do not contain infectious virus. He was able to produce renal carcinomas with cytoplasmic fractions of algid tumours but not with similar preparations of calid ones. However, the presence of the viral genome in calid tumours has been demonstrated in a number of ways. Rafferty (1965) showed that intranuclear inclusions developed in tumours which were free of such inclusions several months after the environment of the host frogs was changed to a temperature of $4^{\circ} \mathrm{C}$. Similar results were obtained by Mizell, Stackpole, and Halperen (1968), and this latter group extended their study to show that virus particles as well as inclusions appeared in tumours, previously free of particles and inclusions, which had been transferred to the anterior chamber of the eye of Rana pipiens and other species of frog and subsequently kept at $7 \cdot 5^{\circ} \mathrm{C}$ (Mizell et al, 1968; Mizell, Stackpole, and Isaacs, 1969). More recently organ cultures of tumours without inclusions have been shown to develop inclusions when the cultures were held at $9^{\circ} \mathrm{C}$ (Morek and Tweedell, see Granoff, 1972). The most convincing evidence for the presence of the viral genome in calid tumours comes from the study of Breidenbach, Skinner, Wallace, and Mizell (1971) who have shown that virus particles can be demonstrated in organ cultures of calid tumours which have been kept at $7.5^{\circ} \mathrm{C}$ but not in those kept at 11.5 and $15 \cdot 5^{\circ} \mathrm{C}$. Finally it has been briefly reported by Mizell (1972) that the use of hybridization techniques has shown the presence in calid tumours of RNA complimentary to the DNA of Lucké herpesvirus.

The accumulation of evidence described above leaves little doubt that the Lucké herpesvirus can exist in a latent and non-productive form. It is also apparent that a non-productive infection is present in tumours of frogs kept in the warm and that this state changes to a productive infection when the temperature is reduced to about $7 \cdot 5^{\circ} \mathrm{C}$ or less. It is also likely that the reverse occurs because intranuclear inclusion-bearing cells of algid tumours die when frogs are moved from cold to warm temperatures (Roberts, 1963; Zambernard and Vatter, 1966).

Under natural conditions most tumours occur in frogs of 3 to 4 years of age. The incidence of tumours in sampled populations can vary greatly, and McKinnell (1969) found from 0 to $12.5 \%$ in samples of frogs taken at different times of year during a number of years. He found that on average tumours were much more frequent in the spring $(5.0 \%)$ and autumn $(4.4 \%)$ than in the summer $(0.14 \%)$. These observations are not consistent with the findings that the incidence and growth rate of tumours in the laboratory are greater when frogs are kept at room temperature rather than in the cold. However, the 
low incidence of tumours in frogs collected in the summer months is probably the result of rapid growth of tumours and resulting death, either from the direct effects of the tumour or by indirect debilitating effects resulting in death from predation (McKinnell, 1969).

Frogs maintained in the laboratory at room temperature for eight months or more commonly have an incidence of tumours of $25 \%$ (Rafferty, 1964). This at first sight appears to be much higher than the incidence in the field. However, samples in the field would be expected to include frogs of all ages, and because tumours probably occur mainly in frogs of 3 years or more of age, the incidence of tumours for the life of a single group of frogs hatched at the same time would be much higher than seen in these samples. The acceleration of tumour growth produced by a long period at room temperature could result in a more realistic incidence of the disease. This figure at least suggests a high incidence of infection with the Lucké herpesvirus in the frog (R. pipiens) population.

In 1964 Rafferty suggested a life cycle for the Lucké herpesvirus and information obtained since that time still supports his suggestion. Experimental production of tumours in frogs has been most successful by exposure of the unfertilized egg to infected material in vivo, and by the inoculation of embryos (Tweedell, 1967, 1969). The production of tumours by inoculation of adults with infective material has been equivocal. These studies suggest that infection is either vertical or, if horizontal, occurs early in life soon after embryonation. Early infection is also suggested by the finding that the incidence of tumours was the same in a group of frogs which were isolated individually, as in a control group kept in crowded conditions (Rafferty, 1963).

It would appear that in most frogs there is no evidence of tumour formation until the autumn of their third or fourth summer. These tumours do not contain virus particles, but soon after entering the lakes for the winter period their temperature is reduced, the tumours cease to grow, and the infective state changes to a productive one. In the spring the frogs emerge from the lakes to spawn. At this time infection is probably passed on vertically or horizontally to the embryos. The parent frogs with tumours survive the breeding period. As the temperature rises the tumour cells with a productive infection die, and the others multiply, resulting in rapid growth of the tumour and death during the summer months.

Although some of this life cycle is based on speculation, much is based on fact. It illustrates that infection of the frog is probably a persistent infection and is without doubt a latent infection in the tumour cells during the summer months. It would be interest- ing to know whether cells other than tumour cells carry the infection, and whether productive and nonproductive infection is seen in such cells according to temperature or whether the non-productive infection is confined to the neoplastic state. It would also be of interest to know whether infection in the cells of calid tumours is cell-associated and whether isolation of the herpesvirus can be made by cocultivation with susceptible cells, as is seen with many of the other herpesviruses associated with tumours.

\section{Herpesvirus of Marek's Disease}

Marek's disease is a common lymphoproliferative disease of the domestic chicken which is caused by a herpesvirus. The disease may occur in chickens of any age above 4 weeks but is most common in the 'adolescent' chicken between 14 and 20 weeks of age. The lymphoproliferation may occur in any organ, but it has an unusual predilection for peripheral nerves, particularly in the less severe forms of the disease. In disease of short duration the changes in nerves are proliferative but they are frequently inflammatory in the more chronic disease.

The epidemiology of Marek's disease has recently been reviewed by Biggs $(1970,1971)$ and Witter (1972). Virus infection is widespread in commercial poultry populations and recent surveys have shown that it is likely that all commercial flocks and probably all or nearly all chickens in each flock become infected with it (Chubb and Churchill, 1968; Sevoian, 1969; Witter, Burgoyne, and Solomon, 1969; Ianconescu and Samberg, 1971; Biggs, Powell, Churchill, and Chubb, unpublished results).

Vertical transmission of infection appears unlikely. Although chickens readily become infected when in direct or indirect contact with infected chickens, or with a contaminated environment, the exact route of infection is not known (see Witter, 1972). However, because airborne transmission has been shown to be effective and because experimentally the respiratory route is the most successful natural route of infection, it is probable that this is the most important route under field conditions.

Newly hatched chicks are free of infection and remain so for variable periods of time. In most flocks infection probably occurs within the first few weeks of life (Witter, Moulthrop, Burgoyne, and Connell, 1970; Biggs, Jackson, Bell, Lancaster, and Milne, 1972) but in some infection may be delayed. Soon after infection virus can be demonstrated in a wide range of tissues and organs. However, infectivity is avidly cell associated in all organs and tissues except the feather follicle epithelium (Biggs and Payne, 1967; Calnek, Ubertini, and Adldinger, 1970; 
Phillips, personal communication). Cell-associated infectivity is greatest in lymphoid organs such as the spleen, bursa of Fabricius, circulating lymphocytes, and lymphoid tumour cells. Although virus-associated antigens may be present in cells of these organs and tissues, in many, such as in tumours, they may be seen only in an occasional cell (Spencer and Calnek, 1970; Calnek and Hitchner, 1969; von Bülow and Payne, 1970; Purchase, 1970). Virus particles are even more rarely seen in tissues other than feather follicles of infected chickens. Virus particles have been seen in a kidney of an infected chicken but not in the infiltrating tumour cells (Schidlovsky, Ahmed, and Jensen, 1969), and Nazerian (1971) has seen virus particles in only two out of 114 tumours and one out of 118 affected nerves. Calnek et al (1970) saw mainly unenveloped virus particles in two out of six bursa of Fabricius and in the gonad and nerves of one out of six chickens. In the epithelial cells of the feather follicle, particularly those near the surface, virus-associated antigens and virus particles (many of them enveloped) are plentiful (Calnek et al, 1970), and disruption of these cells will release infectious virus. Since these cells are continuously being desquamated, and because feather dust and dander have been found to remain infectious for long periods(Beasley, Patterson, and McWade, 1970; Jurajda and Klimeš, 1970), it is believed that this is the major site of shedding of infectious virus and the main source of infection for other chickens.

The time relationships between infection and the development of disease is difficult to follow in naturally infected flocks of chickens. Most information has therefore been derived from studies using experimental infection in which the incubation or latent period can vary greatly. There are a number of factors which affect the susceptibility of a chicken to the disease and the following are probably most important: strain and dose of virus, age, and genetic constitution. These factors will also probably have some influence on the latent period. It would appear that all chickens are susceptible to infection but that there is considerable variability in individual susceptibility to disease. After infection with a single dose of virus the latent period may vary between about 21 to 300 days or perhaps more in different individuals (Biggs and Payne, 1967). Most commercial chickens remain infected throughout their life of about 75 weeks without showing evidence of disease (Witter, Solomon, Champion, and Nazerian, 1971; Biggs et al, 1972).

Antibodies are present in the majority of adult chickens, and $90 \%$ or more of day-old chicks have maternal antibody (Chubb and Churchill, 1968; Witter, 1970). After three to four weeks it has dis- appeared and active antibody is developed about two to two and half weeks after virus infection can first be detected (Witter et al, 1970; Bankowski, Mikami, and Reynolds, 1970; Biggs et al, 1972). Virus can be isolated throughout the life of most chickens that have been infected with Marek's disease virus and antibodies persist throughout the commercial life of the chicken (Witter et al, 1971; Biggs et al, 1972).

It is clear from these observations that infection is widespread amongst poultry populations, and that infection usually persists throughout the life of the chicken.

It is also apparent that latency in respect of disease is a common feature of infection with Marek's disease virus. Frequently the period between infection and the development of clinical disease may be several months, and in many individuals infection does not result in clinical disease. Some of the more important reasons for variability in the latent period have already been mentioned. However in chickens kept under commercial conditions two other possibilities could be responsible. It is now well recognized that many chickens vaccinated with an attenuated form of Marek's disease virus become superinfected with field virus without consequently developing clinical disease (Churchill, Payne, and Chubb, 1969; Biggs, Payne, Milne, Churchill, Chubb, Powell, and Harris, 1970). It is probable that many chickens become infected with more than one strain because virus strains varying in pathogenicity from those that produce little or no disease to those that are oncogenic are ubiquitous amongst poultry populations (Biggs and Milne, 1972). Experimental infection with an apathogenic strain of Marek's disease virus offers some protection against later exposure to a pathogenic strain (Biggs and Milne, unpublished observation). It therefore seems likely that chickens primarily infected in the field with a virus of low virulence are less likely to develop clinical disease following later infection with a fully virulent virus than those primarily infected with a virulent virus. Where disease does occur the latent period could be extended in dual infections where primary infection is with a virus of low virulence.

Anecdotal information backed by some circumstantial evidence suggests that stressing factors may activate disease during the latent period. It is not uncommon to find Marek's disease occurring in flocks of chicken that have been moved from rearing to laying quarters seven to 10 days before. The shortest incubation or latent period for the disease under experimental conditions is between 21 and 28 days. This suggests that chickens is such flocks had been infected before their change in environment. The relationship between movement and disease has 
been observed too often to be a chance occurrence. Rather, it appears that the accumulation of stressing factors which occur at this time and may include travelling, changes in food, debeaking, and vaccination against other diseases, are more likely to be responsible.

At the level of the individual the term 'latency' in this infection can only be applied in respect of the development of disease. Infection is not latent because virus is shed into the environment in an infectious form throughout the life of many chickens (Kenzy and Biggs, 1967; Kenzy and Cho, 1969; Witter et al, 1971).

A latent and non-productive infection may well occur at the level of the cell. Both tumour and circulating white cells are some of the best sources of infected cells. But virus-associated antigens are only present in a few of these cells, and virus particles are rarely seen. In this respect it is interesting that Campbell and Woode (1970) readily found virusassociated antigens and virus particles in cultured circulating lymphocytes which had been stimulated to transform by exposure to phytohaemagglutinin. This work suggests that a more productive infection has been induced from a previous latent or non-productive state.

We can conclude that the virus of Marek's disease is probably latent and non-productive in some tissues, eg, tumour cells, and variably productive in other tissues, eg, it is fully productive in the feather follicle epithelium but abortive in many other tissues.

\section{Conclusions}

There is little difficulty in recognizing that persistent infection is a characteristic of all the viruses considered in this paper. This state is also a common feature of many, if not all, herpesvirus infections in man and animals. Persistent infection is a feature of RNA tumour viruses and it is possible that such infections allow viruses to exhibit the oncogenic potential which they may have.

Latency is more difficult to consider. It is clear that all the virus infections discussed can produce a latent infection if one accepts a long period of infection without disease as an expression of latency.

A cell-associated nature of infectivity is a common feature for most tissues of animals infected by viruses considered in this paper, and particularly of the tumour cells produced by such infections. By this I mean a state in which transfer of infectivity is only possible by co-cultivation of, or contact between, infected cells and uninfected cells. Disruption of infected cells, however carefully done, does not release infectious virus. In these cells, virus particles are usually not or oniy rarely seen, and virus-associated antigen may or may not be identified. This state does not strictly conform to the definition of a non-productive infection given by Roizman (1972). However, it does differ from the productive and cytolytic infections seen in some tissues or under certain conditions, eg, feather follicle epithelium in chickens infected with Marek's disease virus, and in algid tumours of the frog in spring time. It would appear that infection in a single host can probably be non-productive in some cells, and productive, although abortively so, in many others, and fully productive in a restricted number of tissues.

It is interesting to note that a cell-associated state of infectivity is present in all herpesvirus-induced tumours, including Burkitt's lymphoma, a state which can be considered a latent or non-productive infection, at least as far as many of the cells in the infected animal are concerned. If this state is important for the oncogenicity of the infection then it is needed in only some cells of the host, although the number would be directly related to the probability of neoplasia resulting from the infection.

Latency or non-productive infection is by no means unique to the putative and established oncogenic herpesviruses. However, cytolytic productive infection and non-productive latent infections are mutually exclusive in any one cell. The latter state is therefore mandatory for expression of neoplastic potential of infection with a herpesvirus. But nonproductive latent infection does not necessarily result in neoplasia. Nevertheless this state, which is so common in herpesvirus infections, opens the way for the expression of any neoplastic potential which these viruses may have.

\section{References}

Bankowski, R. A., Mikami, T., and Reynolds, B. (1970). The relation between infection of chickens with Marek's disease and the presence of precipitin antibodies. Avian Dis., 14, 723-737.

Beasley, J. N., Patterson, L. T., and McWade, D. H. (1970). Transmission of Marek's disease by poultry house dust and chicken dander. Amer. J. vet. Res., 31, 339-344.

Biggs, P. M. (1970). The epizootiology of Marek's disease. In Comparative Leukemia Research: Proccedings of the IVth International Symposium 1969 (Bibliotheca haematologica), No. 36, edited by R. M. Dutcher, pp. 198-209. Karger, Basle and New York.

Biggs, P. M. (1971). Marek's disease-epizootiology. In Proceedings of the 19th Congress of the World Veterinary Association, Mexico City, pp. 460-462.

Biggs, P. M., Jackson, C. A. W., Bell, R. A., Lancaster, F. M., and Milne, B. S. (1972). A vaccination study with an attenuated Marek's disease virus. In Oncogenesis and Herpesviruses, edited by P. M. Biggs, G. de Thé, and L. N. Payne. IARC Scientific Publication No. 2. International Agency for Research on Cancer, Lyons. (In press.)

Biggs, P. M., and Milne, B. S. (1972). Biological properties of a number of Marek's disease virus isolates. In Oncogenesis and Herpesviruses, edited by P. M. Biggs, G. de Thé, and L. N. Payne. IARC Scientific Publication No. 2. International Agency for Research on Cancer, Lyons. (In press.) 
Biggs, P. M., and Payne, L. N. (1967). Studies on Marek's disease. I. Experimental transmission. J. nat. Cancer Inst., 39, 267-280.

Biggs, P. M., Payne, L. N., Milne, B. S., Churchill, A. E., Chubb, R. C., Powell, D. G., and Harris, A. H. (1970). Field trials with an attcnuated cell associated vaccire for Marek's disease. Vet. Rec., 87, 704-709.

Breidenbach, G. P., Skinner, M. S., Wallace, J. H., and Mizell, M. (1971). In vitro induction of a herpes-type virus in 'summerphase' Lucké tumour explants. J. Virol., 7, 679-682.

von Bủlow, V., and Payne, L. N. (1970). Direktor ImmunofluoreszenzTest bei der Marek'schen Krankheit. Z bl. vet. Med., 17, 460-478.

Calnek, B. W., and Hitchner, S. B. (1969). Localisation of viral antigen in chickens infected with Marek's disease herpesvirus. J. nat. Cancer Inst., 43, 935-949.

Calnek, B. W., Ubertini, T., and Adldinger, H. K. (1970). Viral antigen, virus particles, and infectivity of tissues from chickens with Marek's disease. J. nat. Cancer Inst., 45, 341-351.

Campbell, J. G., and Woode, G. N. (1970). Demonstration of a herpestype virus in short-term cultured blood lymphocytes associated with Marek's disease. J. med. Microbiol., 3, 463-473.

Chubb, R. C., and Churchill, A. E. (1968). Precipitating antibodies associated with Marek's disease. Vet. Rec., 83, 4-7.

Churchill, A. E., Payne, L. N., and Chubb, R. C. (1969). Immunization against Marek's disease using a live attenuated virus. Nature (Lond.), 221, 744-747.

Fawcett, D. W. (1956). Electron microscore observations on intracellular virus-like particles associated with the cells of the Lucké renal adenocarcinoma. J. biophys. biochem. Cytol., 2, $725-742$.

Granoff, A. (1972). Lucké tumour-associated viruses. In Oncogenesis and Herpesviruses, edited by P. M. Biggs, G. de Thé, and L. N. Payne. IARC Scientific Publication No. 2. International Agency for Research on Cancer, Lyons. (In press.)

Hinze, H. C. (1969). Rabbit lymphoma induced by a new herpesvirus. Bact. Proc., 157.

Hinze, H. C. (1971). New member of the herpesvirus group isolated from wild cottontail rabbits. Infect. and Immun., 3, 350-354.

Hsiung, G. D., and Kaplow, L. S. (1969). Herpeslike virus isolated from spontaneously degenerated tissue culture derived from leukemia-susceptible guinea pigs. J. Virol., 3, 355-357.

Hsiung, G. D., Kaplow, L. S., and Booss, J. (1971). Herpesvirus infection of guinea pigs. I. Isolation, characterization and pathogenicity. Amer. J. Epidem., 93, 298-307.

Hunt, R. D., Meléndez. L. V., King, N. W., Gilmore, C. E., Daniel, M. D., Williamson, M. E., and Jones, T. C. (1970). Morphology of a disease with features of malignant lymphoma in marmosets and owl monkeys inoculated with Herpesvirus saimiri. J. nat. Cancer Inst., 44, 447-465.

Ianconescu, M., and Samberg, Y. (1971). Etiological and immunological studies in Marek's disease. II. Incidence of Marek's disease precipitating antibodies in commercial flocks and in eggs. Avian Dis., 15, 177-186.

Jurajda, V., and Klimeš, B. (1970). Presence and survival of Marek's disease agent in dust. Avian Dis., 14, 188-190.

Kenzy, S. G., and Biggs, P. M. (1967). Excretion of the Marek's disease agent by infected chickens. Vet. Rec., 80, 565-568.

Kenzy, S. G., and Cho, B. R. (1569). Transmission of classical Marek's disease by affected and carrier birds. Avian Dis., 13, 211-214.

Ley, K. D., and Burger, D. (1970). Cell-associated nature of cottontail rabbit herpesvirus in vitro. Appl. Microbiol., 19, 549-550.

Lucké, B. (1934). A neoplastic disease of the kidney of the frog, Rana pipiens. Amer. J. Cancer, 20, 352-379.

Lucké, B. (1938). Carcinoma in the leopard frog: its probable causation by a virus. J. exp. Med., 68, 457-468.

Lunger, P. D., Darlington, R. W., and Granoff, A. (1965). Cell-virus relationship in the Lucké renal adenocarcinoma: an ultrastructural study. Ann. N.Y. Acad. Sci., 126, 289-314.

Mackay, J. M. K. (1969a). Tissue culture studies of sheep pulmonary adenomatosis (Jaagsiekte). I. Direct cultures of affected lungs. J. comp. Path., 79, 141-146.

Mackay, J. M. K. (1969b). Tissue culture studies of sheep pulmonary adenomatosis (Jaagsiekte). II. Transmission of cytopathic effects to normal cultures. J. comp. Path., 79, 147-154.

Mackay, J. M. K., and Nisbet, D. I. (1972). Pathogenicity tests in lambs with an ovine herpesvirus. In Oncogenesis and Herpesviruses, edited by P. M. Biggs, G. de Thé, and L. N. Payne. IARC Scientific Publication No. 2. International Agency for Research on Cancer, Lyons. (In press.)

McKinnell, R. G. (1969). Lucké renal adenocarcinoma: epidemiological aspects. In Biology of Amphibian Tumors (Recent
Results in Cancer Research, Spec. Suppl.), edited by M. Mizell, pp. 254-260. Springer, New York.

McKinnell, R. G., and Ellis, V. L. (1972). Epidemiology of the frog renal tumour and the significance of tumour transplantation studies to a viral aetiology of the tumour. In Oncogenesis and Herpesviruses, edited by P. M. Biggs, G., de Thé, and L. N. Payne. IARC Scientific Publication No. 2. International Agency for Research on Cancer, Lyons. (In press.)

McKinrell, R. G., and Zambernard, J. (1968). Virus particles in renal tumors obtained from spring Rana pipiens of known geographic origin. Cancer Res., 28, 684-688.

Meléndez, L. V., Daniel, M. D., Hunt, R. D., and Garcia, F. G. (1968). An apparently new herpesvirus from primary kidney cultures of the squirrel monkey (Saimiri sciureus). Lab. Animal Care, 18, 374-381.

Meléndez, L. V., Hunt, R. D., Daniel, M. D., Blake, B. J., and Garcia, F. G. (1971). Acute lymphocytic leukemia in owl monkeys inoculated with Herpesvirus saimiri. Science, 171, 1161-1163.

Meléndez, L. V., Hunt, R. D., Daniel, M. D., Fraser, C. E. O., Barahona, H. H., Garcia, F. G., and King, N. W. (1972). Lymphoma viruses of monkeys: Herpesvirus saimiri and Herpesvirus ateles, the first oncogenic herpesviruses of primates. In Oncogenesis and Herpesviruses, edited by P. M. Biggs, G. de Thé, and L. N. Payne, IARC Scientific Publication No. 2. International Agency for Research on Cancer, Lyons. (In press.)

Meléndez, L. V., Hunt, R. D., Daniel, M. D., Garcia, F. G., and Fraser, C. E. O. (1969). Herpesvirus saimiri. II. Experimentally induced malignant lymphoma in primates. Lab. Animal Care. $19,378-386$.

Mizell, M. (1972). The Lucké tumour herpesvirus-its presence and expression in tumour cells. In Oncogenesis and Herpesviruses, edited by P. M. Biggs, G. de Thé, and L. N. Payne, IARC Scientific Publication No. 2. International Agency for Research on Cancer, Lyons. (In press.)

Mizell, M., Stackpole, C. W., and Halperen, S. (1968). Herpes-type virus recovery from 'virus-free' frog kidney tumors. Proc. Soc. exp. Biol. (N.Y.), 127, 808-814.

Mizell, M., Stackpole, C. W., and Isaacs, J. J. (1969). Herpestype virus latency in the Lucké tumor. In Biology of Amphibian Tumors (Recent Results in Cancer Research, Spec. Suppl.) edited by M. Mizell, pp. 337-347. Springer, New York.

Nazerian, K. (1971). Further studies on the replication of Marek's disease virus in the chicken and in cell culture. J. nat. Cancer Inst., 47, 207-217.

Nisbet, D. I., Mackay, J. M. K., Smith, W., and Gray, E. W. (1971). Ultrastructure of sheep pulmonary adenomatosis (Jaagsiekte). J. Path., 103, 157-162.

Perk, K., Hod, I., and Nobel, T. A. (1971). Pulmonary adenomatosis of sheep (Jaagsiekte). I. Ultrastructure of the tumor. J. nat. Cancer Inst., 46, 525-537.

Purchase, H. G. (1970), Virus-specific immunofluorescent and precipitin antigens and cell-free virus in the tissues of birds infected with Marek's disease. Cancer Res., 30, 1898-1908.

Rafferty, K. A., Jr. (1963). Spontaneous kidney tumors in the frog: rate of ozcurrence in isolated adults. Science, 141, 720-721.

Rafferty, K. A., Jr. (1964). Kidney tumours of the leopard frog: a review. Cancer Res., 24, 169-185.

Rafferty, K. A., Jr. (1965). The cultivation of inclusion-associated viruses from Lucké tumor frogs. Ann. N.Y. Acad. Sci., 126, 3-21.

Roberts, M. E. (1963). Studies on the transmissibility and cytology of the renal carcinoma of Rana pipiens. Cancer Res., 23, 170\%. 1714.

Roizman, B. (1972). The biochemical features of herpesvirus-infected cells, particularly as they relate to their potential oncogenicity. In Oncogenesis and Herpesviruses, edited by P. M. Biggs, G. de Thé, and L. N. Payne, IARC Scientific Publication No. 2. International Agency for Research on Cancer, Lyons. (In press.)

Schidlovsky, G. Ahmed, M., and Jensen, K. E. (1969). Herpesvir u in Marek's disease tumors. Science, 164, 959-961.

Sevoian, M. (1969). Studies for the control of Type II (Marek's) leukosis. In Proceedings of the 4th Congress of the World's Veterinary and Poultry Association, Belgrade, pp. 259-266.

Smith, W., and Mackay, J. M. K. (1969). Morphological observations of a virus associated with sheep pulmonary adenomatosis (Jaagsiekte). J. comp. Path., 79, 421-424.

Spencer, J. L., and Calnek, B. W. (1970). Marek's disease: application of immunofluorescence for detection of antigen and antibody. Amer. J. vet. Res., 31, 345-358. 
Tweedell, K. S. (1967). Induced oncogenesis in developing frog kidney cells. Cancer Res., 27, 2042-2052.

Tweedell, K. S. (1969). Simulated transmission of renal tumors in oocytes and embryos of Rana pipiens. In Biology of Amphibian Tumors (Recent Results in Cancer Research. Spec. Suppl.), edited by M. Mizell, pp. 229-239. Springer, New York.

Witter, R. L. (1970). Epidemiological studies relating to the control of Marek's disease. Wld. Poult. Sci.J., 26, 755-762.

Witter, R. L. (1972). Epidemiology of Marek's disease. In Oncogenesis and Herpesviruses, edited by P. M. Biggs, G. de Thé, and L. N. Payne. IARC Scientific Publication No. 2. International Agency for Research on Cancer, Lyons. (In press.)

Witter, R. L., Burgoyne, G. H., and Solomon, J. J. (1969). Evidence for a herpesvirus as an etiologic agent of Marek's disease. Avian Dis., 13, 171-184.

Witter, R. L., Moulthrop, J. I., Jr., Burgoyne, G. H., and Connell, H. C. (1970). Studies on the epidemiology of Marek's disease herpesvirus in broiler flocks. Avian Dis., 14, 255-267.

Witter, R. L., Solomon, J. J., Champion, L. R., and Nazerian, K.
(1971). Long term studies of Marek's disease infection in individual chickens. Avian Dis., 15, 346-365.

Wolfe, L. G., Folk, L. A., and Deinhardt, F. (1971). Oncogenicity of Herpesvirus saimiri in marmoset monkeys. J. nat. Cancer Inst. 47, 1145-1162.

Zambernard, J., and McKinnell, R. G. (1969). 'Virus free' renal tumors obtained from prehibernating leopard frogs of known geographic origin. Cancer Res., 29, 653-657.

Zambernard, J., and Mizell, M. (1965). Virus particles of the frog renal adenocarcinoma: causative agent or passenger virus? I. Fine structure of primary tumors and subsequent intraocular transplants. Ann. N.Y. Acad. Sci., 126, 127-145.

Zambernard, J., and Vatter, A. E. (1966). The effect of temperature change upon inclusion-containing renal tumor cells of leopard frogs. Cancer Res., 26, 2148-2153.

Zambernard, J., Vatter, A. E., and McKinnell, R. G. (1966). The fine structure of nuclear and cytoplasmic inclusions in primary renal tumors of mutant leopard frogs. Cancer Res., 26, 1688-1700. 